\title{
Pendidikan Islam sebagai Fondasi Pendidikan Karakter
}

\author{
Abdah Munfaridatus Sholihah \\ Fakultas Tarbiyah IAI Sunan Giri Ponorogo \\ abdahmunfarida.20@gmail.com \\ Windy Zakiya Maulida \\ Pascasarjana IAI Sunan Giri Ponorogo \\ winmaulida95@gmail.com
}

Naskah diterima: 13 Januari 2020| Naskah disetujui: 11 Maret 2020

\begin{abstract}
Education in Indonesia is faced with the problem of low morals, in particular among teenagers, such as brawls between students, promiscuity, drugs, and a lack of respect for teachers. In the field of education, the cultivation of students' character needs to receive great attention. Strengthening character education in the present context is very relevant to overcome the moral crisis that is happening in this country. This condition of moral decadence indicates that the inculcation of religious teachings and character values obtained in school has not been entirely successful because they have not shown significant results on changes in student behavior in their lives. Character education in Islam is in principle based on two main sources of Islamic teachings, namely the Qur'an and Hadith. Thus the parameter of good and bad in a person's character has a certain standard according to the Qur'an and Hadith. As the basis of Islamic education, the Qur'an and Al-Hadith are references to seek, create, and develop paradigms, concepts, principles, theories, and techniques of Islamic education, even in every educational effort. Because it is sourced from the two main teachings of Islam, Islamic education is called the foundation for character education.
\end{abstract}

Keywords: Islamic education, character education

\begin{abstract}
Abstrak
Pendidikan di Indonesia dihadapkan pada masalah rendahnya akhlak terutama di kalangan remaja, misalnya adanya tawuran antar pelajar, pergaulan bebas, narkoba, serta kurangnya sikap hormat kepada guru. Dalam bidang pendidikan, penanaman karakter terhadap peserta didik perlu mendapat perhatian besar. Penguatan pendidikan karakter dalam konteks kekinian sangat relevan untuk menanggulangi krisis moral yang sedang melanda di negara ini. Kondisi dekadensi moral ini menandakan bahwa penanaman nilai agama dan nilai karakter yang didapatkan di bangku sekolah belum sepenuhnya berhasil karena belum menampakkan hasil yang signifikan terhadap perubahan perilaku peserta didik dalam kehidupannya. Pendidikan karakter dalam Islam pada prinsipnya didasarkan pada dua sumber pokok ajaran Islam, yaitu Al-Qur'an dan Hadis. Dengan demikian, parameter baik dan buruk dalam karakter seseorang memiliki standar tertentu menurut Al-Qur'an dan Hadis. Sebagai dasar pendidikan Islam, Al-Qur'an dan Hadis adalah rujukan untuk mencari, membuat, dan mengembangkan paradigma, konsep, prinsip, teori, dan teknik pendidikan Islam, termasuk juga dalam setiap upaya pendidikan. Karena bersumber dari Al-Qur'an dan Hadis yang
\end{abstract}


merupakan pokok ajaran Islam, maka pendidikan Islam disebut sebagai fondasi bagi pendidikan karakter.

Kata kunci: pendidikan Islam, pendidikan karakter

\section{Pendahuluan}

Dalam Undang-Undang Republik Indonesia Nomor 20 tahun 2003 tentang Sistem Pendidikan Nasional disebutkan bahwa pendidikan adalah usaha sadar dan terencana untuk mewujudkan suasana belajar dan proses pembelajaran agar peserta didik secara aktif mengembangkan potensi dirinya untuk memiliki kekuatan spiritual keagamaan, pengendalian diri, kepribadian, kecerdasan, akhlak mulia, serta keterampilan yang diperlukan dirinya, masyarakat, bangsa, dan Negara (UU Sisdiknas Nomor 20 Tahun 2003).

Indonesia merupakan negara yang kaya akan sumber daya alam (SDA) dan sumber daya manusia (SDM). Kekayaan alam Indonesia meliputi ribuan pulau yang berjajar mulai dari Sabang sampai Merauke dengan kandungan yang ada pada tiap-tiap pulau, baik dari hasil laut maupun di luar laut. Di sisi lain, kualitas SDM akan menentukan kualitas bangsa. Untuk itu, kualitas SDM perlu ditingkatkan melalui berbagai program pendidikan yang dilaksanakan secara sistematis dan terarah berdasarkan kepentingan yang mengacu pada kemajuan ilmu pengetahuan dan teknologi (IPTEK) dan dilandasi oleh keimanan dan ketaqwaan (IMTAQ).

Pendidikan merupakan upaya yang terencana dalam proses pembimbingan dan pembelajaran bagi individu agar tumbuh berkembang menjadi manusia yang mandiri, bertanggung jawab, kreatif, berilmu, sehat, dan berakhlak (berkarakter) mulia. Fungsi dan tujuan pendidikan nasional, seperti yang tertulis dalam Undang-Undang Nomor 20 Tahun 2003, menegaskan bahwa pendidikan nasional berfungsi mengembangkan kemampuan dan membentuk watak serta peradaban bangsa yang bemartabat dalam rangka mencerdaskan kehidupan bangsa, bertujuan untuk berkembangnya potensi peserta didik agar menjadi manusia yang beriman dan bertakwa kepada Tuhan Yang Maha Esa, berakhlak mulia, sehat, berilmu, cakap, kreatif, mandiri, dan menjadi warga negara yang demokratis serta bertanggung jawab (UU Sisdiknas Nomor 20 Tahun 2003).

Dari rumusan tersebut terlihat bahwa pendidikan nasional berfungsi untuk membangun manusia yang memiliki nilai karakter yang mulia. Membicarakan karakter merupakan hal yang sangat penting dan mendasar dalam dunia pendidikan. Karakter merupakan mustika hidup yang membedakan manusia dengan makhluk lainnya. Dalam Kamus Besar Bahasa Indonesia, karakter adalah sifat-sifat kejiwaan, akhlak atau budi pekerti yang membedakan seseorang dari yang lain; tabiat; watak (KBBI Online).

Fakta yang sekarang dapat kita lihat bahwa pendidikan di Indonesia dihadapkan pada masalah rendahnya moral dan akhlak terutama di kalangan remaja, misalnya adanya tawuran antar pelajar, pergaulan bebas, narkoba, serta kurangnya sikap hormat kepada guru. Dalam bidang pendidikan, penanaman karakter terhadap peserta didik seharusnya lebih ditekankan lagi. Mengingat begitu urgennya karakter, maka institusi pendidikan memiliki tanggung jawab untuk menanamkannya pada proses pembelajaran.

Penguatan pendidikan karakter dalam konteks sekarang sangat relevan untuk mengatasi krisis moral yang sedang terjadi di negara kita. Kondisi dekadensi moral ini menandakan bahwa penanaman nilai agama dan nilai karakter yang didapatkan di bangku sekolah belum sepenuhnya 
berhasil karena belum menampakkan hasil yang signifikan terhadap perubahan perilaku peserta didik dalam kehidupannya.

Menurut Sudarminta sebagaimana dikutip Zubaedi (2011: 3), praktik pendidikan yang semestinya memperkuat aspek karakter atau nilai-nilai kebaikan sejauh ini hanya mampu menghasilkan berbagai sikap atau perilaku manusia yang nyata-nyata malah bertolak belakang dengan apa yang diajarkan. Dicontohkan juga bagaimana Pendidikan Moral Pancasila (PMP) dan Agama pada masa lalu merupakan dua jenis mata pelajaran tata nilai, yang ternyata tidak berhasil menanamkan sejumlah nilai moral dan humanis ke dalam pusat kesadaran siswa. Materi yang diajarkan oleh pendidikan agama termasuk di dalamnya bahan ajar akhlak, cenderung terfokus pada pengayaan intelektual (kognitif) saja, sedangkan pembentukan sikap (afektif) dan pembiasaan (psikomotorik) masih terbilang minim. Pembelajaran pendidikan agama masih didominasi oleh sekadar transfer ilmu pengetahuan agama saja dan lebih banyak bersifat hafalan tekstual, sehingga aspek sosial mengenai nilai dan ajaran hidup masih kurang menyentuh.

Melihat pengertian dan fungsi pendidikan yang tertulis dalam UU Sisdiknas Nomor 20 Tahun 2003 dapat disimpulkan bahwa pendidikan harus mampu mengemban misi pembentukan karakter (character building) sehingga para peserta didik dapat sepenuhnya menanamkan nilai karakter mulia. Permasalahan pendidikan karakter tersebut telah terjawab sejak munculnya Kurikulum 2013 yang memiliki dasar penguatan pendidikan karakter bagi peserta didik.

Tidak hanya itu, pendidikan Islam juga mengemban misi utama memanusiakan manusia, yaitu mampu menjadikan manusia mengembangkan seluruh potensi yang dimilikinya sehingga berfungsi secara maksimal sesuai dengan aturan-aturan yang ditetapkan Allah sehingga dapat mewujudkan insan kamil. Di antara tanda manusia yang paripurna adalah dengan dimilikinya akhlak atau karakter mulia. Maka dalam hal ini pendidikan Islam juga merupakan sarana untuk membentuk karakter peserta didik.

\section{Pendidikan Islam}

Pendidikan Islam merupakan salah satu aspek dari ajaran Islam secara keseluruhan, karena tujuan pendidikan Islam tidak terlepas dari tujuan hidup manusia dalam Islam, yaitu untuk menciptakan pribadi-pribadi hamba Allah Swt. yang selalu bertaqwa kepadaNya dan mencapai kehidupan yang bahagia di dunia dan di akhirat. Keimanan seseorang hanya dapat dilihat dari amal perbuatannya, sebab amal perbuatan menjadi indikator yang amat penting untuk mengukur keimanan seorang muslim. Apabila dikaitkan dengan pendidikan Islam yang bertujuan mencetak anak didik yang beriman, wujud dari tujuan itu adalah akhlak anak didik, sedangkan akhlak anak didik itu mengacu pada kurikulum yang diterapkan dalam pendidikan yang dilaksanakan di berbagai lembaga, baik lembaga pendidikan formal maupun nonformal (Akhdiyat, 2007: 345).

Pendidikan secara teoretis yaitu seperangkat pengetahuan yang telah tersusun secara sistematis yang berfungsi untuk menjelaskan, menggambarkan, mengontrol berbagai gejala dan peristiwa pendidikan baik yang bersumber pada pengalaman pendidikan maupun hasil perenungan yang mendalam untuk melihat makna pendidikan dalam konteks yang lebih luas. Praktis pendidikan adalah seperangkat kegiatan yang bertujuan membantu pihak lain agar mengalami perubahan tingkah laku yang diharapkan (Tafsir, 2010: 20).

Pendidikan diartikan juga sebagai latihan mental, moral, dan fisik (jismiyah) yang menghasilkan manusia berbudaya tinggi untuk melaksanakan tugas kewajiban dan tanggung jawab 
dalam masyarakat selaku hamba Allah. Materi pendidikan ini dimaksudkan agar manusia mampu menghadapi dan mengatasi kesulitan dan tantangan menuju kesempurnaan hidup yang membutuhkan tenaga, kekuatan dan kesehatan, dan agar tidak mengkhawatirkan kondisi tubuhnya dan kesejahteraannya. Pendidikan Islam seperti pada umumnya berusaha membentuk pribadi manusia melalui proses panjang, dengan hasil yang tidak dapat diketahui segera. Pendidikan Islam harus memahami dan menyadari betul apa sebenarnya yang ingin dicapai (tujuan) dalam proses pendidikan (Ramayulis, 2006: 132).

Dalam pelaksanaannya, pendidikan sebagai proses timbal balik antara pendidik dan anak didik melibatkan faktor-faktor pendidikan guna mencapai tujuan pendidikan yang didasari oleh nilai-nilai tertentu. Nilai-nilai mendalam itulah yang kemudian disebut sebagai dasar-dasar pendidikan. Istilah dasar-dasar pendidikan dimaksudkan sebagai landasan tempat berpijak atau fondasi berdirinya suatu sistem pendidikan. Dasar pendidikan Islam identik dengan dasar Islam itu sendiri. Keduanya berasal dari sumber yang sama, yaitu Al-Qur'an dan Al-Hadis. Dari kedua sumber inilah kemudian muncul sejumlah pemikiran mengenai masalah umat Islam yang meliputi berbagai aspek, termasuk di antaranya masalah paradigm pendidikan Islam. Oleh karena itu, secara garis besar, sumber penelaahan pendidikan Islam dapat diidentifikasi ke dalam dua corpus, yaitu: Al-Qur'an dan Al-Hadis (Basri, 2014: 18).

Sebagai dasar pendidikan Islam, Al-Qur'an dan Al-Hadis adalah rujukan untuk mencari, membuat, dan mengembangkan paradigma, konsep, prinsip, teori, dan teknik pendidikan Islam.AlQur'an dan Al-Hadis merupakan rujukan dalam setiap upaya pendidikan. Artinya, rasa dan pikiran manusia yang bergerak dalam kegiatan pendidikan mestilah bertolak dari keyakinan tentang kebenaran Al-Quran dan Al-Hadis. Selain itu, keduanya juga merupakan kerangka normatif-teoretis pendidikan Islam. Keduanya adalah sumber nilai kehidupan manusia dalam berbagai aspeknya, yang telah memperkenalkan dan mengajar manusia untuk selalu berpikir (Basri, 2014: 18).

Secara ontologis, pendidikan Islam adalah hakikat dari kehidupan manusia sebagai makhluk yang berakal dan berpikir. Epistemologi pendidikan Islam adalah seluk beluk dan sumber-sumber pendidikan Islam, sebagaimaa telah ditegaskan bahwa Al-Qur'an sebagai segala sumber hukum dalam ajaran Islam. Pendidikan Islam merujuk pada nilai-nilai Al-Qur'an yang abadi. Aksiologi pendidikan Islam berkaitan dengan visi dan misi, etika, estetika, tujuan, dan target yang akan dicapai dalam pendidikan (Basri, 2014: 18-19).

Dalam ajaran Islam, seluruh aktivitas manusia bertujuan untuk meraih tercapainya insan yang beriman dan bertakwa. Apabila anak didik telah beriman dan bertakwa, maka tujuannya telah tercapai. Keimanan seseorang hanya dapat dilihat dari amal perbuatannya sebab amal perbuatan menjadii indikator yang amat penting untuk mengukur keimanan seorang muslim. Apabila dikaitkan dengan pendidikan Islam yang bertujuan untuk mencetak anak didik yang beriman, wujud dari tujuan itu adalah anak didik. Dalam kehidupan sehari-hari, indikator tercapainya tujuan pendidikan Islam adalah bergaul dengan sesama manusia dengan baik dan benar serta mengamalkan amar ma'ruf nahi munkar kepada sesama manusia (Basri, 2014: 189).

Muhammad Athiyah Al-Abrasyi mengungkapkan bahwa tujuan umum dari pendidikan Islam adalah pembentukan akhlak dan budi pekerti yang sanggup menghasilkan orang-orang yang bermoral, berjiwa bersih, pantang menyerah, bercita-cita tinggi, dan berakhlak mulia.Selain itu juga mengerti kewajiban masing-masing, dapat membedakan antara yang baik dan buruk, mampu menyusun skala prioritas, menghindari perbuatan tercela, mengingat Tuhan dan mengetahui setiap pekerjaan yang dilakukan.Secara singkat karakteristik pendidikan Islam, di antaranya adalah: 
a. Pendidikan Islam adalah penekanan pencarian ilmu pengetahuan, penguasaan, dan mengembangkan atas dasar ibadah kepada Allah Swt.

b. Pengakuan akan potensi dan kemampuan seseorang, berkembang dalam suatu kepribadian.

c. Pengalaman ilmu pengetahuan atas dasar tanggung jawab kepada Tuhan dan masyarakat.

Dapat disimpulkan bahwa karakteristik pendidikan Islam adalah beribadah kepada Allah Swt. Dengan demikian konsep pendidikan Islam tidak terlepas dari tujuan hidup manusia, yakni untuk menciptakan hamba Allah yang bertakwa kepada-Nya dan dapat mencapai kehidupan bahagia di dunia dan akhirat (Basuki dan Ulum, 2007: 14). Menurut Al-Attas, pada prinsipnya pendidikan itu bertujuan untuk melahirkan manusia yang baik, manusia adab atau insan kamil yang beriman kepada Allah Swt. sebagai khaliq yang menciptakannya (Baharudin, 2007: 76).

Tujuan akhir pendidikan Islam menurut Asma Hasan Fahmi ialah tujuan keagaamn, tujuan pengembangan akal dan akhlak, tujuan pengajaran dan kebudayaan, tujuan pembinaan kepribadian. Menurut Munir Mursi sebagaimana dikutip Tafsir (2010: 49), tujuan pendidikan Islam ialah sebagai berikut: bahagia di dunia dan akhirat, menghambakan diri kepada Allah, memperkuat ikatan keislaman dan melayani kepentingan masyarakat Islam, akhlak mulia. Perlu ditegaskan sekali lagi bahwa tujuan pendidikan Islam secara esensial adalah terwujudnya anak didik yang memahami ilmu-ilmu keislaman dan mengamalkannya dalam kehidupan sehari-hari. Dengan kata lain, terwujudnya insan kamil, yakni manusia yang kembali kepada fitrahnya dan kepada tujuan kehidupannya sebagaimana ia berikrar sebagai manusia yang datang dari Allah dan kembali kepada Allah (Basri, 2014: 192). Al-Qur'an dan Al-Hadis mewajibkan umat Islam mencari ilmu dan membangun lembaga pendidikan Islam. Karena dengan ilmu pendidikan Islam, umat Islam akan terhindar dari pendidikan yang berbasis kepada nilai-nilai sekuleritas dan faham liberalisme. Pendidikan Islam dibangun bukan hanya sekadar pengguguran kewajiban, tetapi sebagai cita-cita dan tujuan hidup umat Islam (Basri, 2014: 193).

\section{Pendidikan Karakter}

Karakter merupakan "keseluruhan disposisi kodrati dan disposisi yang telah dikuasai secara stabil yang mendefinisikan seorang individu dalam keseluruhan tata perilaku psikisnya yang menjadikannya tipikal dalam cara berpikir dan bertindak (Zubaedi, 2011: 8). Sebagai aspek kepribadian, karakter merupakan cerminan dari kepribadian secara utuh dari seseorang: mentalitas, sikap, dan perilaku. Karakter selalu berkaitan dengan dimensi fisik dan psikis individu. Karakter bersifat kontekstual dankultural. Karakter bangsa merupakan jati diri bangsa yang merupakan kumulasi dari karakter-karakter warga masyarakat suatu bangsa.

Karakter (character) mengacu pada serangkaian pengetahuan (cognitives), sikap (attitude), perilaku (behavior), motivasi (motivation), dan keterampilan (skill). Karakter meliputi sikap seperti keinginan untuk melakukan hal yang terbaik, kapasitas intelektual seperti kritis dan alasan moral, perilaku seperti jujur dan bertanggung jawab, mempertahankan prinsip-prinsip moral dalam situasi penuh ketidakadilan, kecakapan interpersonal dan emosional yang memungkinkan sesorang berinteraksi secara efektif dalam berbagai keadaan, dan komitmen untuk berkontribusi dengan komunitas dan masyarakatnya. Karakter merupakan nilai-nilai perilaku manusia yang berhubungan dengan Tuhan Yang Maha Esa, diri sendiri, sesama manusia, lingkungan, dan kebangsaan yang terwujud dalam pikiran, sikap, perasaan, perkataan, dan perbuatan berdasarkan norma-norma agama, hukum, tata krama, budaya, dan adat istiadat (Abdur Rohman, 2019). 
Pendidikan karakter tidak hanya mengajarkan mana yang benar dan mana yang salah kepada peserta didik, tetapi juga menanamkan kebiasaan (habituation) tentang yang baik sehingga peserta didik paham, mampu merasakan, dan mau melakukannya (Marzuki, 2007: 23). Individu juga memiliki kesadaran untuk berbuat yang terbaik atau unggul, dan individu juga mampu bertindak sesuai potensi dan kesadarannya tersebut. Individu yang berkarakter baik atau unggul merupakan seseorang yang berusaha melakukan hal-hal yang terbaik terhadap Tuhan Yang Maha Esa, dirinya, sesama, lingkungan, bangsa dan negara serta dunia internasioanl pada umumnya dengan mengoptimalkan potensi (pengetahuan) dirinya dan disertai dengan kesadaran, emosi, dan motivasi (Zubaedi, 2011: 11).

Karakter seseorang berkembang berdasarkan potensi yang dibawa sejak lahir atau yang dikenal sebagai karakter dasar yang bersifat biologis. Menurut Ki Hajar Dewantara, aktualisasi karakter dalam bentuk perilaku sebagai perpaduan antara karakter biologis dan hasil hubungan atau interaksi dengan lingkungannya. Karakter dapat dibentuk melalui pendidikan, karena pendidikan merupakan alat yang paling efektif untuk menyadarkan individu dalam jati diri kemanusiaannya. Dengan pendidikan akandihasilkan kualitas manusia yang memiliki kehalusan budi dan jiwa, memiliki kecermelangan pikir, kecekatan raga, dan memiliki kesadaran penciptaan dirinya (Zubaedi, 2011: 13).

Pendidikan karakter diartikan sebagai the deliberate us of all dimensions of school life to foster optimal character development (usaha kita secara sengaja dari seluruh dimensi kehidupan sekolah untuk membantu pengembangan karakter secara optimal) (Zubaedi, 2011: 14). Penekanan pendidikan karakter tidak terbatas pada transfer pengetahuan mengenai nilai-nilai yang baik, namun lebih dari itu menjangkau pada bagaimana menjadikan nilai-nilai tersebut tertanam dan menyatu dalam totalitas pikiran-tindakan.

Pendidikan karakter merupakan proses pembudayaan dan pemberdayaan nilai-nilai luhur dalam lingkungan satuan pendidikan (sekolah), lingkungan keluarga, dan lingkungan masyarakat. Nilai-nilai luhur ini berasal dari teori-teori pendidikan, psikologi pendidikan, nilai-nilai sosial budaya, ajaran agama, Pancasila dan UUD 1945, dan UU No. 20 Tahun 2003 tentang Sistem Pendidikan Nasional, serta pengalaman terbaik dan praktik nyata dalam kehidupan sehari-hari.

Pendidikan karakter dipahami sebagai upaya penanaman kecerdasan dalam berpikir, penghayatan dalam bentuk sikap, dan pengamalan dalam bentuk perilaku yang sesuai dengan nilainilai luhur yang menjadi jati dirinya, diwujudkan dalam interaksi dengan Tuhannya, diri sendiri, antarsesama, dan lingkungannya. Nilai-nilai luhur tersebut antara lain: kejujuran, kemandirian, sopan santun, kemuliaan sosial, kecerdasan berpikir, termasuk keingintahuan akan ilmu pengetahuan, dan berpikir logis. Oleh karena itu, penanaman pendidikan karakter tidak bisa hanya sekadar mentransfer ilmu pengetahuan atau melatih suatu keterampilan tertentu. Penanaman pendidikan karakter perlu proses, contoh teladan, dan pembiasaan atau pembudayaan dalam lingkungan peserta didik dalam lingkungan sekolah, keluarga, lingkungan masyarakat, maupun lingkungan (exposure) media massa (Zubaedi, 2011: 17).

Proses pendidikan karakter ataupun pendidikan akhlak dipandang sebagai usaha sadar dan terencana, bukan usaha yang sifatnya terjadi secara kebetulan. Atas dasar ini, pendidikan karakter adalah usaha yang sungguh-sungguh untuk memahami, membentuk, memupuk nilai-nilai etika, baik untuk diri sendiri maupun untuk semua warga masyarakat atau warga negara secara keseluruhan. Berkenaan dengan pendidikan ini, kita diingatkan bahwa "Education comes from within; you get it by struggle, effort, and thought" oleh Napoleon Hill, yang artinya: pendidikan 
datang dari dalam diri kita sendiri, Anda memperolehnya dengan perjuangan, usaha, dan berpikir (Zubaedi, 2011: 20).

\section{Pendidikan Islam sebagai Fondasi Pendidikan Karakter}

Pendidikan karakter bukan hal yang baru dalam sistem pendidikan Islam, sebab roh atau inti dari pendidikan Islam adalah pendidikan karakter yang semula dikenal dengan pendidikan akhlak. Pendidikan Islam sudah ada sejak Islam mulai didakwahkan oleh Nabi Muhammad Saw., kepada para sahabatnya. Seiring dengan penyebaran Islam, pendidikan karakter tidak pernah diabaikan karena Islam yang disebarkan oleh Nabi adalah Islam dalam arti yang utuh, yaitu keutuhan dalam iman, amal saleh, dan akhlak mulia. Dari sinilah dapat dipahami bahwa sebenarnya orang muslim yang kafah adalah seorang muslim yang memiliki iman yang kuat, lalu mengamalkan seluruh perintah Allah dan menjauhi seluruh larangan-Nya, serta akhirnya memiliki sikap dan perilaku (akhlak) mulia sebagai konsekuensi dari iman dan amal salehnya (Marzuki, 2017: 5-6).

Pembinaan akhlak atau karakter sebenarnya menjadi tanggung jawab setiap umat Islam yang dimulai dari tanggung jawab terhadap dirinya lalu keluarganya. Ketika disadari bahwa tidak semua umat Islam mampu mengemban tanggung jawab tersebut, tanggung jawab untuk melakukannya berada pada orang-orang (kaum muslim) yang memiliki kemampuan untuk itu. Para guru (ustadz) dan para $d a{ }^{\prime} i$ memiliki tanggung jawab untuk pembinaan karakter umat Islam melalui pendidikan Islam, baik di institusi formal maupun nonformal, sementara orang tua (pemimpin keluarga) memiliki tanggung jawab pendidikan karakter dalam institusi pendidikan informal.

Pendidikan karakter di sekolah yang semula dibebankan melalui dua mata pelajaran, yaitu Pendidikan Agama dan Pendidikan Kewarganegaraan, ternyata tidak membawa hasil seperti yang diharapkan. Pengembangan karakter peserta didik di sekolah harus melibatkan lebih banyak lagi mata pelajaran, bahkan semua mata pelajaran. Selain itu, kegiatan pembinaan kesiswaan dan pengelolaan sekolah dari hari ke hari perlu juga dirancang dan dilaksanakan untuk mendukung pendidikan karakter di kelas (Marzuki, 2017: 7).

Pendidikan karakter di lingkungan keluarga dan di sekolah merupakan dua pilar utama dari tiga pusat pendidikan, termasuk pendidikan karakter, yang dapat menjadi penyangga bagi terwujudnya karakter di kalangan peserta didik yang pada akhirnya akan menjadi manusia dewasa yang bertebaran di tengah-tengah masyarakat. Pendidikan karakter di sekolah dan keluarga harus benar-benar diupayakan agar dapat menjadi pagar yang kondusif dalam membangun karakter anak terutama dalam menghadapi kemungkinan-kemungkinan munculnya hambatan di tengah-tengah masyarakat.Pendidikan karakter akan menjadi sangat efektif ketika kedua pilar pendidikan ini menyatu bersama dalam membangun karakkter anak (Marzuki, 2007: 7-8).

Perlu ditegaskan bahwa Islam adalah agama sempurna yang memiliki ajaran yang paling lengkap di antara agama-agama yang pernah diturunkan oleh Allah Swt. kepada umat manusia.Untuk memahami dan mengamalkan ajaran Islam secara mendasar, setiap muslim harus memahami dan mengamalkan dasar-dasar Islam yang biasa dikenal dengan kerangka dasar ajaran Islam. Kerangka dasar ini merupakan garis besar yang mendasari semua nilai dan konsep yang ada dalam ajaran Islam. Selain itu, kerangka ini terkait erat dengan tujuan ajaran Islam. Secara umum, tujuan pengajaran atau pendidikan Islam adalah membina manusia agar mampu memahami, menghayati, meyakini, dan mengamalkan ajaran Islam sehari-hari sehingga menjadi insan kamil, yaitu seorang muslim yang beriman, bertakwa kepada Allah Swt., dan berakhlak mulia. Adapun 
kerangka dasar ajaran Islam juga meliputi tiga konsep kajian dasar, yaitu akidah, syariah, dan akhlak (Marzuki, 2007: 9).

Dari konsep dasar ini ulama mengembangkannya menjadi tiga konsep kajian. Konsep iman melahirkan konsep kajian akidah, konsep Islam melahirkan konsep kajian syariah, dan konsep ihsan melahirkan konsep kajian akhlak. Kajian yang ketiga inilah yang sekarang popular dengan istilah pendidikan karakter. Sehubungan dengan itu, Ibnu Taimiyah menjelaskan bahwa ketiga urutan di atas (Islam, iman, dan ihsan) merupakan penjenjangan dalam meraih derajat yang dimulai dari Islam kemudian meningkat menjadi iman dan akhirnya menjadi ihsan (Marzuki, 2017: 11). Ihsan terkait erat dengan pendidikan budi pekerti atau pendidikan karakter. Al-Qur'an menegaskan bahwa orang yang paling baik agamanya adalah orang yang muhsin.

Seperti ditegaskan sebelumnya bahwa pendidikan karakter sebenarnya merupakan inti dari pendidikan Islam. Oleh karena itu, kajian pendidikan karakter dalam Islam tidak bisa dilepaskan dari kajian Islam pada umumnya. Untuk melengkapi pemahaman tentang pendidikan Islam, berikut ini akan dikemukakan beberapa karakteristik pendidikan Islam:

a. Pendidikan Islam merupakan bagian yang tidak dapat dipisahkan dari ajaran Islam karena melalui pendidikan Islam inilah seseorang akan menjadi seorang muslim yang memiliki bekal yang cukup untuk melaksanakan ajaran Islam.

b. Pendidikan Islam bertujuan mewujudkan peserta didik yang beriman dan bertakwa kepada Allah Swt., berbudi pekerti luhur, serta memiliki pengetahuan yang cukup tentang sumber ajaran dan sendi-sendi Islam lainnya. pada saat bersamaan, pendidikan Islam dapat dijadikan bekal untuk mempelajari berbagai bidang ilmu lainnya sehingga akan memperkuat pembentukan karakter dan keilmuan.

c. Pendidikan Islam tidak hanya menekankan pada penguasaan kompetensi yang bersifat kognitif, tetapi yang lebih penting adalah pencapaian pada aspek afektif (sikap) dan psikomotor (perilaku). Hasil dari pendidikan Islam adalah sikap dan perilaku (karakter) peserta didik sehari-hari yang sejalan dengan ajaran Islam.

d. Seluruh ajaran Islam, termasuk pendidikan Islam, didasarkan pada dua sumber pokok ajaran Islam, yaitu Al-Qur'an dan Hadis (dalil naqli). Sementara itu, dengan metode ijtihad (dalil aqli), ulama mengembangkan prinsip-prinsip pendidikan Islam yang telah terperinci dan detail dalam bentuk fiqh dan hasil-hasil ijtihad lainnya.

e. Prinsip-prinsip dasar pendidikan Islam tertuang dalam tiga kerangka dasar ajaran Islam, yaitu akidah, syariah, dan akhlak. Dari ketiga prinsip dasar itulah berkembang berbagai kajian keislaman, seperti ilmu kalam (teologi Islam, ushuluddin, atau ilmu tauhid) yang merupakan pengembangan dari akidah; ilmu fiqh yang merupakan pengembangan dari syariah; dan ilmu akhlak (etika Islam, moralitas Islam, pendidikan karakter Islam) yang merupakan pengembangan dari akhlak.

f. Tujuan akhir dari pendidikan Islam adalah terbentuknya peserta didik yang memiliki akhlak mulia (manusia berkarakter). Tujuan ini yang sebenarnya misi utama diutusnya Nabi Saw. Dengan demikian pendidikan akhlak (pendidikan karakter) adalah jiwa dari pendidikan Islam (Marzuki, 2017: 13-14). 


\section{Analisis}

Seperti yang telah dijelaskan di atas, karakter identik dengan akhlak, sehingga karakter merupakan nilai-nilai perilaku manusia yang meliputi seluruh aktivitasnya baik dalam hubungan dengan Tuhan, diri sendiri, sesama manusia, maupun lingkungannya. Karakter atau yang juga disebut dengan akhlak memiliki kedudukan yang sangat penting dalam ajaran Islam, karena hal ini berkaitan dengan misi utama diutusnya Rasulullah Muhammad Saw. ke bumi yaitu untuk menyempurnakan akhlak. Begitu juga pendidikan Islam menempati posisi penting dalam pendidikan karakter. Dengan berlandaskan Al-Qur'an dan Hadis, pendidikan Islam bertujuan untuk mewujudkan manusia yang beriman dan bertakwa kepada Allah Swt., serta memiliki karakter atau akhlak mulia. Dalam perspektif Islam, karakter atau akhlak mulia merupakan hasil dari proses syariah (ibadah dan muamalah) yang berdasarkan pada fondasi akidah (keimanan) yang kokoh.

Pendidikan karakter dalam Islam pada prinsipnya didasarkan pada dua sumber pokok ajaran Islam, yaitu Al-Qur'an dan Hadis.Dengan demikian ukuran baik dan buruk dalam karakter seseorang memiliki standar menurut Al-Qur'an dan Hadis.Dalam perspektif Islam, umumnya karakter dibagi menjadi dua, yaitu karakter mulia (al-akhlaq al-mahmudah) dan karakter tercela (alakhlaq al-madzmumah). Karakter dalam Islam terdiri dari karakter atau akhlak terhadap khaliq (Allah Swt.) dan karakter atau akhlak terhadap makhluq (selain Allah).Karakter terhadap Allah adalah sikap dan perilaku manusia dalam berhubungan dengan Allah, (hablun minallah). Karakter terhadap makhluk selain Allah Swt. bisa dirinci menjadi beberapa macam, seperti karakter terhadap sesama manusia, karakter terhadap selain manusia, seperti hewan dan tumbuhan, serta karakter terhadap lingkungan.

Akhlak menunjukkan banyak nilai tentang karakter manusia, baik yang bernilai baik maupun buruk. Melalui kedua sumber yaitu Al-Qur'an dan Hadis dapat diketahui bahwa sifat-sifat sabar, qana'ah, tawakkal, syukur, pemaaf, ikhlas, dermawan, dan pemurah termasuk sifat-sifat yang baik dan mulia. Sifat-sifat syirik, kufur, takabbur, nifak, ujub, iri hati, su'udzan, dan hasad merupakan sifat-sifat tercela. Nilai-nilai karakter tersebut dapat ditanamkan salah satunya melalui pendidikan.

Seperti telah dijelaskan pada teori di atas, bahwa pendidikan Islam merupakan salah satu aspek dari ajaran Islam secara keseluruhan, karena tujuan pendidikan Islam tidak terlepas dari tujuan hidup manusia dalam Islam, yaitu untuk menciptakan pribadi-pribadi hamba Allah Swt. yang selalu bertaqwa kepada-Nya dan mencapai kehidupan yang bahagia di dunia dan di akhirat. Pendidikan karakter merupakan misi utama dari pendidikan Islam yang tujuan tertingginya adalah terwujudnya manusia paripurna (insan kamil), yaitu manusia yang beriman dan bertakwa kepada Allah Swt., serta memiliki akhlak atau karakter yang mulia. Pelaksanaan pendidikan karakter yang bersumber dari nilai-nilai pendidikan Islam di sekolah antara lain dapat dilaksanakan dengan cara penyelenggaraan kegiatan ekstrakurikuler keagamaan, seperti shalat berjama'ah, kantin kejujuran, hingga tadarus al-Qur'an dan buka puasa bersama di bulan Ramadhan, serta silaturahim kepada guru dan tokoh masyarakat di bulan Syawal (Setyowati, 2018). Secara aktif dalam proses pembelajaran di ruang kelas, dapat juga dengan menggunakan, misalnya, metode diskusi dilema moral, termasuk juga berdasarkan nilai-nilai pendidikan Islam, yang terbukti mampu meningkatkan karakter peserta didik secara empiris (Murdianto, 2019).

Karena bersumber dari Al-Qur'an dan Hadis yang merupakan pokok ajaran Islam, maka pendidikan Islam disebut sebagai fondasi bagi pendidikan karakter. Aspek kognitif bukan satusatunya hal yang harus ditekankan dalam konsep pendidikan Islam, tetapi lebih penting pada aspek 
afektif (sikap) dan psikomotor (perilaku). Hasil dari pendidikan Islam adalah penerapan sikap dan perilaku (karakter) peserta didik dalam kehidupan sehari-hari yang sesuai dengan ajaran Islam. Nilai-nilai karakter yang ditanamkan pada peserta didik berpijak kepada konsep dan praktik-praktik berkarakter sesuai yang dicontohkan oleh Nabi Saw.yang merupakan cerminan dari akhlak AlQur'an. Jika pendidikan Islam dilaksanakan dengan baik dan berhasil mencapai tujuannya yaitu insan kamil, maka ummat Islam akan menjadi manusia-manusia yang berkarakter.

\section{Kesimpulan}

Untuk menanamkan pendidikan karakter tidak bisa hanya sekadar mentransfer ilmu pengetahuan saja. Namun dalam penanaman karakter perlu adanya proses, teladan yang baik, dan pembiasaan yang terus menerus dilakukan, baik dalam lingkungan sekolah, keluarga, maupun masyarakat. Pendidikan Islam pada puncaknya bertujuan untuk membentuk manusia paripurna (insan kamil), yaitu manusia yang berakhlak mulia. Dengan demikian, pendidikan akhlak (pendidikan karakter) adalah jiwa dari pendidikan Islam.

Penanaman nilai-nilai karakter yang baik telah dicontohkan oleh Nabi Saw. sebagai suri teladan yang baik bagi ummat Islam. Sumber pokok dari ajaran Islam adalah Al-Qur'an dan Hadis. Karakter yang telah ditanamkan pada peserta didik dalam proses pendidikan didasarkan pada dua pokok sumber ajaran tersebut, sehingga pendidikan Islam disebut sebagai fondasi bagi pendidikan karakter.

\section{Referensi}

Abdur Rohman, M. (2019). Pendidikan Karakter di Sekolah Menengah Pertama (SMP): Teori, Metodologi dan Implementasi. QALAMUNA: Jurnal Pendidikan, Sosial, Dan Agama, 11(2), 265-286. https://doi.org/10.5281/zenodo.3559290

Akhdiyat. (2007). Ilmu Pendidikan Islam. Bandung: Insan Mandiri.

Baharudin, K. (2007). Filsafat Pendidikan Islam. Yogyakarta: Pustaka Pelajar.

Basri, H. (2014). Filsafat Pendidikan Islam. Bandung: Pustaka Setia.

Basuki \& Ulum, M. (2007). Pengantar Pendidikan Islam.Ponorogo: STAIN Po Press.

Marzuki. (2017). Pendidikan Karakter Islam. Jakarta: Amzah.

Murdianto. (2019). Keefektifan Metode Diskusi Dilema Moral Untuk Meningkatkan Penalaran Moral Peserta Didik Mamnu Ponorogo. Scaffolding : Jurnal Pendidikan Islam dan Multikulturalisme, $1(01)$ 1-15. https://ejournal.insuriponorogo.ac.id/index.php/scaffolding/article/view/38

Ramayulis. (2006). Ilmu Pendidikan Islam. Jakarta: Kalam Mulia.

Setyowati, N. (2018). Pendidikan Karakter Di Lembaga Pendidikan Islam (Studi Kasus Tentang Implementasi Pendidikan Karakter Di Mtsn Ponorogo Dan Mts Ma'arif 1 Ponorogo). AlAdabiya: Jurnal Kebudayaan Dan Keagamaan, 12(2), 185-207. https://doi.org/10.37680/adabiya.v12i2.14

Tafsir, A. (2010). Ilmu Pendidikan dalam Perspektif Islam.Bandung:Remaja Rosdakarya.

Zubaedi. (2011). Desain Pendidikan Karakter: Konsepsi dan Aplikasinya dalam Lembaga Pendidikan. Jakarta: Kencana Prenada Media Group. 